\title{
Yield Trials with Xanthosoma Varieties
}

\section{A. Acosta Matienzo and J. Vélez Santiago ${ }^{1}$}

\section{INTRODUCTION}

The genus Xanthosoma is a member of the Aroid family of plants native to Tropical America. Several species of this genus have been cultivated for their edible tubers and stems since pre-Columbian times. These plant species are known in Puerto Rico by the collective Indian name of yautias and in the British West Indies as taniers.

They are starchy staple food crops which, because of their large per acre production and relatively low labor requirements, occupy an important position in the agriculture and diet of many tropical countries including Puerto Rico. According to official figures, yautia production in Puerto Rico for the year 1964-65 amounted to 354,000 hundredweights of stems and tubers valued at $\$ 2,620,000(2){ }^{2}$ The greatest part of this production was consumed directly by the population in rural areas. Another portion went to towns and cities. The remainder was shipped to the mainland of the United States. Shipments to the United States during 1964-65 amounted to 46,646 hundredweights; 1,925 hundredweights were imported that year from the Dominican Republic.

Table 1 shows a breakdown, by types and classes, of the wholesale volume in the principal rural and city markets of the Island for the year 1962-63. The classes are based largely on consumer preferences in relation to flesh color and quality. The highest price per hundredweight of tubers and stems, or \$8.96, was for the Yellow class which is highly valued for its excellent quality, while the lowest price, or $\$ 6.25$, was for "other" varieties. The largest volume of sales, 50,072 hundredweights, was for the Purple class. In other years, however, the White class has been in greatest supply. The least supply, or 3,088 hundredweights, was in the Yellow class which always is in short supply.

A collection of the most important tanier varieties was established at the Agricultural Experiment Station several years ago to provide material for study and evaluation. The purpose of this paper is to present results of three evaluation experiments with 15 varieties conducted at three different towns in the Island.

1 Assistant Agronomist and Research Assistant, respectively, Gurabo Substation, Agricultural Experiment Station, Mayagüez Campus, University of Puerto Rico, Río Piedras, P.R.

Italic numbers in parentheses refer to Literature Cited, p. 568-9. 


\section{DESCRIPTION OF THE VARIETIES}

Most cultivated Xanthosoma varieties in Puerto Rico, according to available information, probably belong to one of three species, $X$. atrovirens, $X$. violaceum and $X$. caracu. The most important varieties, from a commercial standpoint, are Vinola, Kelly, Rascana, Viequera, Blanca and Martinica (1)..$^{3}$ Following is a brief description of the varieties compared in the field trials.

The varieties Martinica and Martinica Amarilla probably belong to $X$. atrovirens; their flesh is firm, yellow-orange, and of excellent quality. The main stems (madres) are edible and constitute the largest part of the commercial production: stem flesh is considerably softer than that of the tubers. The latter are few in number and are small and irregular in shape.

TABLE 1.-Tanier or yautia wholesale records at the principal city and rural public markets of Puerto Rico, by type or class, 1968-691

\begin{tabular}{l|c|c|c}
\hline Type or class & Quantity & Price & Value \\
\cline { 2 - 3 } & Cwt. & Dollars/cot. & Dollars \\
Yellow & 3,088 & 8.96 & 27,674 \\
White & 36,700 & 8.54 & 313,351 \\
Kelly & 15,221 & 8.92 & 135,754 \\
Purple & 50,072 & 7.73 & 387,302 \\
Other & 14,770 & 6.25 & 92,355 \\
Total & 119,851 & $7.98^{2}$ & 956,436 \\
\hline
\end{tabular}

1 From Department of Agriculture, Commonwealth of Puerto Rico, Special Publication No. 10, pp. 13-15, June 1964.

2 Average price.

The variety Rascana is of uncertain classification. It produces an abundant number of tubers of medium size which are cream-colored and of firm flesh. Raphides sometimes are present in the tubers; the quality of the variety, although acceptable, is not considered to be the best.

The variety Vinola belongs most likely to $X$. violaceum. It produces a fair number of perhaps the largest tubers of all the varieties, are of uniform

The classes in table 1 roughly coincide with the specific designation of the varieties. The Yellow class includes the varieties of $X$. atrovirens but does not include the Kelly variety which, although yellow fleshed, stands out as a class by itself and possibly belongs to $X$. violaceum. The Purples include the Vinola variety and similar clones and belong to $X$. violaceum. The Whites mostly include the varieties or clones of $X$. caracu and possibly, although to a lesser extent, other distinct unclassified varieties such as Inglesa. The Rascana, as well as other unclassified material, probably come under "Others." 
shape with wine-colored flesh. The pulp is soft after cooking and is of very good taste and quality.

The variety Kelly, although yellow-fleshed, is distinctly different from the varieties of $X$. atrovirens. For this reason and because it resembles the Vinola vegetatively, it was tentatively assigned to $X$. violaceum. It produces a fair number of good-sized, uniform-shaped tubers. The flesh is yellow, rather soft after cooking, and is thus distinct from the varieties Martinica and Martinica Amarilla.

Dominicana is another variety of uncertain designation. Vegetatively it shows affinity towards $X$. violaceum varieties because of the strong coloration in its leaves and petioles. It is very striking in appearance; the violet black color of the petioles are also covered with a glaucous-blue bloom. Tubers are few in number, medium to small in size, and rather irregular or spherical in shape. Their flesh is cream colored and firm in consistency after cooking.

The majority of the white-fleshed varieties in the Island and in the collection probably belong to $X$. caracu. Farmers and consumers in general refer to all these groups as yautia blanca. There are about eight different clones or varieties of this species in the Experiment Station collection. Some of these resemble each other quite closely and may be similar and possibly identical. Others differ notably in the size and shape of the tubers as well as in total production. Yautía Blanca and Viequera are the two most outstanding varieties of this species in the Island and in the collection. They produce an abundant number of large-sized tubers which are rather long, mace-like and uniform in shape; very narrow at the point of attachment to the stem and wide at the distal end. The flesh is medium soft after cooking and of very good quality. The variety Viequera differs from the variety Yautia Blanca in the darker coloration of the skin of the tubers. It also is said to be more drought-resistant. Other varieties, such as Drearies, Barbados, Charanelle, and Choubutton were received from the Agricultural Experiment Station of Trinidad and these resemble the varieties Blanca and the Viequera. The varieties Blanca de Pais and Bisely differ in the size and shape of the tubers as well as in total production.

- Inglesa is a white-fleshed variety of undetermined species, distinct from the other white flesh varieties belonging to $X$. caracu with regard to its vegetative characters. This variety produces numerous medium to small, irregularly shaped tubers of good quality and yield.

\section{MATERIALS AND METHODS}

Three experiments were conducted to evaluate the yields of 15 yautia varieties. One experiment was planted February 28, 1961 at the Gurabo 
Substation. The other two experiments were planted May 9 and 24, 1963 at Naranjito and the Corozal Substation. The Gurabo experiment was established on a fairly well drained Toa loam soil; 4 the one at Naranjito on a moderate to steep-sloped Cialitos clay soil, ${ }^{5}$ and the one at Corozal on a level Lares clay soil. ${ }^{6}$ The Lares soil had a $\mathrm{pH}$ of 4.55 and was limed at the rate of 4 tons of calcium carbonate per cuerda, ${ }^{7}$ while the Toa and Cialitos soils had a pH of 5.2 and 5.6, respectively, and were not limed.

Each experiment followed a $3 \times 4$ triple rectangular lattice design. Pieces of the main stem (madre), each with an average of two buds, were used as seed. These were planted in rows 3 feet apart and 2 feet within the row. Plots were $15 \times 20$ feet with five rows of 10 plants each.

A 12-6-16 fertilizer was applied in two portions, 2 ounces per plant in the hole at planting time and 2 ounces 2 months later. Cultivation followed accepted practices.

The plants in the Gurabo experiment were harvested on April 2, 1962, 13 months from planting date; those at Corozal and Naranjito were harvested March 2 and 9, 1964, respectively, 9 to 10 months from the planting date. The prevailing dry weather, however, typical of February and March, ended the period of active growth during the three experiments.

After harvest, soil and roots were removed from the tubers which then were classified as "marketable" and "non marketable." Data was recorded as to number and weight of tubers according to variety and class. Main stems (madres) in addition to the tubers also were considered as part of the yield in $X$. atrovirens varieties.

- Toa loam is a soil from river flood plains, formed from material washed from the interior bills, which is carried and distributed by silt-laden overflowing streams. The plains are nearly level, have good drainage, are friable and deep, thus being almost ideal for maximum agricultural utilization. They contain considerable organic matter, sand and soil nutrients, and are slightly acid (4).

- Cialitos clay soil is derived from parental volcanic tuffs and shale beds where annual rainfall exceeds 75 inches. It occurs both in slopes and on ridges of hills. It is characterized by a friable, finely granular clay surface soil which extends to the average depth of plowing where it gradulaly changes to a medium heavy but permeable plastic clay. It is acid, more so with depth, and is commonly planted to coffee, tobacco and staple crops, left uncultivated or planted to grass (4).

- Lares clay is derived from the wash of red, acid clay soils and occupies very old high, well-drained terraces that have been eroded to strongly undulating to rolling relief. It is characterized by slightly granular, medium-friable, acid-clay surface soil about 7 inches thick with a medium compact, slightly plastic, clay subsoil to a depth ranging from 24 to 30 inches; beyond, lies an acid silty clay substratum wbich rests on gravel at a depth of $\mathbf{5}$ feet. This soil is fairly permeable, deep, well-drained and fairly rich in plant nutrients. It is used rather successfully for most crops grown in the Island (4).

7 A cuerda is equivalent to 0.9712 acre. 
TABLE 2.-Yields per cuerda1 obtained in three tanier or yautia variety evaluation experiments.

\begin{tabular}{|c|c|c|c|c|c|c|c|c|}
\hline \multicolumn{3}{|c|}{ Gurabo } & \multicolumn{3}{|c|}{ Naraniito } & \multicolumn{3}{|c|}{ Corozal } \\
\hline \multicolumn{2}{|c|}{ Variety } & \multirow{2}{*}{ Yield per cuorda } & \multicolumn{2}{|c|}{ Variety } & \multirow{2}{*}{ Yield per cuerda } & \multicolumn{2}{|c|}{ Variety } & \multirow{2}{*}{ Yield per cuerdo } \\
\hline Number & Name & & Number & Name & & Number & Name & \\
\hline $\begin{array}{r}9 \\
10 \\
7 \\
11 \\
12 \\
4 \\
5 \\
3 \\
6 \\
8 \\
\\
1 \\
\end{array}$ & \begin{tabular}{l} 
Viequera \\
Bisley \\
Rascana \\
Blanca \\
Rascana \\
Kelly \\
Inglesa \\
Vinola \\
Dominicana \\
Blanca del \\
\multicolumn{1}{c}{ País } \\
Martinica \\
Amarilla \\
Martinica
\end{tabular} & $\begin{array}{c}\text { Hundredweight } \\
129 \\
128 \\
112 \\
111 \\
111 \\
86 \\
84 \\
79 \\
65 \\
60 \\
\\
23 \\
21\end{array}$ & $\begin{array}{r}8 \\
4 \\
7 \\
5 \\
12 \\
9 \\
6 \\
11 \\
1 \\
10 \\
2 \\
\\
\\
3\end{array}$ & $\begin{array}{l}\text { Rascana } \\
\text { Rascana } \\
\text { Blanca } \\
\text { Viequera } \\
\text { Drearies } \\
\text { Choubutton } \\
\text { Bisley } \\
\text { Barbados } \\
\text { Vinola } \\
\text { Charanelle } \\
\text { Kelly } \\
\text { Dominicana }\end{array}$ & $\begin{array}{c}\text { Bundredwoight } \\
112 \\
115 \\
106 \\
104 \\
101 \\
99 \\
98 \\
83 \\
79 \\
61 \\
39 \\
23\end{array}$ & $\begin{array}{r}4 \\
12 \\
5 \\
2 \\
7 \\
11 \\
8 \\
9 \\
6 \\
10 \\
\\
1 \\
\\
\end{array}$ & $\begin{array}{l}\text { Rascana } \\
\text { Drearies } \\
\text { Viequera } \\
\text { Kelly } \\
\text { Blanca } \\
\text { Barbados } \\
\text { Rascana² } \\
\text { Choubutton } \\
\text { Bisley } \\
\text { Charanelle } \\
\text { Vinola } \\
\text { Dominicana }\end{array}$ & $\begin{array}{c}\text { Busdredweight } \\
105 \\
104 \\
87 \\
81 \\
76 \\
75 \\
73 \\
62 \\
61 \\
55 \\
53 \\
48\end{array}$ \\
\hline \multicolumn{3}{|c|}{ Significant differences at 5-percent level } & \multicolumn{3}{|c|}{ Significant differences at 5 -percent level } & \multicolumn{3}{|c|}{ Significant differences at 5-percent level } \\
\hline \multicolumn{3}{|c|}{$9,10,7,11,12>2,1$} & \multicolumn{3}{|c|}{$8,4,7,5,12,9,6>3,2 \quad 11,1,>3$} & \multicolumn{3}{|c|}{ None } \\
\hline $\bar{x}=59.6$ & $S=340.8$ C.V & 1 percent & $\vec{x}=60$ & $S=162.3 \mathrm{C}$. & 21 percent & $\bar{x}=52$. & $S=245.8 \quad \mathrm{C} . \mathrm{V}$ & 30 percent \\
\hline
\end{tabular}

1 A cuerda is equivalent to 0.9712 acre.

- Material obtained from a commerical source and included originally under a different varietal name. 


\section{RESULTS AND DISCUSSION}

The yields of Xanthosoma varieties in the Gurabo, Naranjito and Corozal experiments, as expressed in hundredweights of commercial tubers ${ }^{8}$ per cuerda, are shown in table 2. Significant differences between the varieties at the 5-percent level were determined following the Tukey's test. No significant differences were noted in the Corozal experiment. Only extreme values were significantly different at Naranjito and Gurabo. However, when individual variety records for the three experiments are arranged by rate of production (table 2), Rascana, Viequera, Drearies and Blanca varieties appear to be among the most productive varieties.

The highest yield per cuerda, or 129 hundredweights of tubers, was produced by the variety Viequera planted in the Gurabo experiment. This is

TABLE 3.-Average weight of commercial tubers obtained in three yautia or tanier variety evaluation experiments

\begin{tabular}{|c|c|c|c|c|c|}
\hline \multicolumn{2}{|c|}{ Gurabo } & \multicolumn{2}{|c|}{ Naranjito } & \multicolumn{2}{|c|}{ Corozal } \\
\hline Variety & $\begin{array}{c}\text { Average tuber } \\
\text { weight }\end{array}$ & Variety & $\begin{array}{c}\text { Average tuber } \\
\text { weight }\end{array}$ & Variety & $\begin{array}{c}\text { Average tuber } \\
\text { weight }\end{array}$ \\
\hline & Ounces & & Ounces & & Ounces \\
\hline Vinola & 6.4 & Vinola & 7.2 & Barbados & 4.8 \\
\hline Blanca & 6.3 & Blanca & 5.7 & Charanelle & 4.6 \\
\hline Viequera & 5.9 & Barbados & 5.3 & Blanca & 4.5 \\
\hline Kelly & 5.6 & Drearies & 5.2 & Viequera & 4.4 \\
\hline Dominicana & 5.5 & Charanelle & 5.1 & Choubutton & 4.4 \\
\hline Rascana & 5.1 & Viequera & 4.8 & Drearies & 4.4 \\
\hline Bisley & 4.7 & Choubutton & 4.8 & Kelly & 4.1 \\
\hline Inglesa & 4.4 & Kelly & 4.8 & Vinola & 4.0 \\
\hline Blanca del País & 4.4 & Bisley & 4.4 & Dominicana & 3.6 \\
\hline $\begin{array}{l}\text { Martinica } \\
\text { Amarilla }\end{array}$ & 3.9 & Dominicana & 3.9 & Bisley & 3.5 \\
\hline Martinica & 3.6 & Rascana & 3.8 & Rascana & 3.5 \\
\hline
\end{tabular}

approximately $63 / 2$ tons per cuerda, a yield considerably less than the 13.8 tons per acre reported by $\mathbf{H}$. G. Gooding et al. (3) from the variety Barbados in an experiment conducted in Trinidad. Conditions of growth and uniformity of stand were not satisfactory in the Corozal experiment, but the stand was good in Naranjito and growth there compared favorably with commercial fields in the vicinity.

Average weight expressed in ounces of tubers for each variety in each experiment is shown in table 3. As in the case of yield (table 2), only general tendencies may be discernible when the data is studied. The

8 Except for the varieties Martinica and Martinica Amarilla, the yields of which included main stems. 
variety Vinola grown under favorable conditions appears capable of producing the largest tubers among the varieties tested, although the varieties Blanca, Viequera, Barbados, Drearies and Choubutton, all of which are derivatives of $X$. caracu, also bear large tubers. The variety Rascana produces small to medium-sized tubers.

The mean yield $(\bar{X})$, standard error $(S)$ and coefficient of variability (C.V.) are included at the bottom of table 2. The Naranjito experiment has the lowest C.V. value, or 21 percent; this is comparable to the error for plots obtained by H. G. Gooding et al. (3) in his experiment. The experiments at Corozal and Gurabo had higher C.V. values, or 31 and 30 percent, respectively.

Results of these experiments, in general, are not conclusive. Further evaluation should be undertaken. The varieties appear to differ in response to soil and climatic factors. Variation in yield is great between plants of the same variety. Three replications are insufficient to furnish adequate information. Plot size, however, possibly could be reduced.

\section{SUMMARY}

Fifteen Xanthosoma varieties were tested for yield in three different experiments conducted at the Gurabo Substation in 1961-62 and at Naranjito and Corozal in 1963-64. Significant differences at the 5-percent level were observed only between very high yielding and very low yielding varieties in the Gurabo and the Naranjito experiments.

Although results were inconclusive, the varieties Rascana, Viequera, Blanca and Drearies may be considered among the highest producers because of their consistently good performance.

\section{RESUMEN}

Se compararon 15 variedades del género Xanthosoma en pruebas de rendimiento en Gurabo, en 1961-62 y en Naranjito y Corozal, en 1963-64. Se observaron diferencias significativas al nivel del 5 por ciento solamente entre las variedades de mayor y menor rendimiento en los experimentos de Gurabo y Naranjito.

Aunque los resultados obtenidos son inconclusos podemos indicar que las variedades Rascana, Viequera, Blanca y Drearies están entre las mejores a base de un rendimiento consistentemente superior.

\section{LITERATURE CITED}

1. Acosta Matienzo, A., Identificación y Descripción de las Variedades de Yautía (Xanthosoma) en la Colección de la Subestación de Gurabo, Agr. Exp. Sta., Univ. P.R., Misc. Pub. 67, July, 1969. 
2. Dept. Agr., Commonwealth of P.R., Facts and Figures on Puerto Rico Agriculture 1965, Spec. Pub. No. 14, pp. 9, 54-5, 1965.

3. Gooding, H. G. and Campbell, J. S., Preliminary trials of West Indian Xanthosoma cultivars, Trop. Agr. 88 (2): 145-52, 1961.

4. Roberts, R. C., Soil Survey of Puerto Rico, U.S. Dept. of Agri., Bureau of Plant Industry, Series 1936 (8) pp. 190-92, 269-73, 313-16, 1942. 